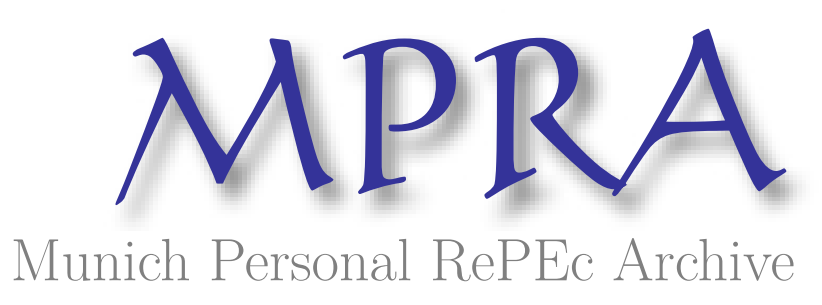

Some Empirical Evidence on the Demand
for Money in the Pacific Island Countries

Kumar, Saten and Singh, Rup

Auckland University of Technology

19 July 2009

Online at https://mpra.ub.uni-muenchen.de/18703/

MPRA Paper No. 18703, posted 18 Nov 2009 10:36 UTC 


\title{
Some Empirical Evidence on the Demand for Money in the Pacific Island Countries
}

\author{
Rup Singh ${ }^{1}$ and Saten Kumar ${ }^{2}$ \\ ${ }^{1}$ School of Economics, University of the South Pacific (Fiji) and ${ }^{2}$ School of Business Economics \\ Auckland University of Technology (New Zealand)
}

\begin{abstract}
This paper explores the stability of the demand for narrow money in the Pacific Island Countries viz, Fiji, Vanuatu, Samoa, Solomons and Papua New Guinea (PNG). The results from the time series approaches of LSE-Hendry's General to Specific (GETS) and Johansen's Maximum Likelihood (JML) suggest that real income, nominal rate of interest and real narrow money, are cointegrated. The CUSUM and CUSUMSQ stability test results indicate that the demand for money functions for these countries are stable and therefore the respective monetary authorities may consider targeting money supply in their conduct of monetary policy.
\end{abstract}

KEYWORDS: Cointegration, Demand for Money, General to Specific Method and Johansen Maximum Likelihood Method.

JEL: C22, E41

\section{Introduction}

Despite the relative paucity of Pacific Island Countries (PICs) economic data in many areas, there are few islands in which economic data and in particular, the money stock and income are provided by their central banks. Limitations in the data have resulted in only a limited number of empirical studies that investigated the long run relationship of money demand in the PICs. For instance, see Katafono (2001), Kannapiran (2001), Jayaraman and Ward (2003), Rao and Singh (2005a and b), Rao and Kumar (2007), Kumar and Manoka (2008) and Singh and Kumar (2009). The correct specification of both long- and short- run demand for money functions is important. Many central banks are in the process of liberalizing their financial sector and therefore success of such policies requires the accurate estimation of the magnitude of the money demand elasticities.

Money supply can be a useful instrument of monetary policy if demand for money is stable. According to Poole (1970) policy makers should target the rate of interest if the $L M$ curve 
is unstable and the level of money supply if the $I S$ curve is unstable. However, instability in $L M$ is largely caused by the instability in the money demand function. Therefore, it is important to test for the stability of the demand for money. Furthermore, following the financial reforms of the mid-1980s, many developed countries have switched to interest rate targeting when their money demand functions became unstable. Unfortunately, many developing countries have also started targeting the rate of interest, even though there is no significant evidence that their money demand functions have become unstable. Consequently, there have been a large number of empirical studies, in both the developed and developing countries, to re-estimate demand for money and to investigate, afresh, its stability; see Sriram (1999) and Rao and Kumar (2009) for details.

The objective of this paper is to analyze money demand functions for the selected PICs and evaluate their stability. In particular, this is the first paper in the literature that provides long run estimates and stability results of the money demand using the newest time series techniques for a group of PICs over the period 1974-2004 [1]. The selected five PICs based on the availability of consistent data are: Fiji (FJ), Vanuatu (VNT), Samoa (SAM), Solomons (SOL) and the Papua New Guinea (PNG). Our results indicate that income elasticities in these countries are close to unity, except for the PNG where it is higher, and the interest rate elasticities are negative, well determined and significant. Most importantly, we found that the money demand functions are temporally stable. We assert that the financial sector reforms and liberalization is yet to have any significant effects on money demand in the PICs and hence the respective monetary authorities may consider money supply as an appropriate instrument of the monetary policy.

Our paper is organized as follows: In Section 2 we briefly survey empirical works on the demand for money in the PICs. Section 3 detail our model specification and data and Section 4 discusses our empirical results. Conclusions are stated in the final Section 5.

\section{Empirical Studies in the PICs}

Empirical studies on demand for money in the PICs are only a handful and available for only Fiji, PNG, Samoa and Tonga. These studies are Katafono (2001), Kannapiran (2001), Jayaraman and Ward (2003), Rao and Singh (2005a and b), Rao and Kumar (2007), Kumar and Manoka (2008) and Singh and Kumar (2009). Though these studies do find some evidence of long run relationship of money demand, some of them seem to have limitations either in their specification or empirical findings.

Katafono (2001) employed annual data from 1975-1999 to estimate demand for narrow money (MI) for Fiji with the Johansen Maximum Likelihood (JML) technique. She found an implausibly low income elasticity (at around 0.60) and asserts that the demand for $M 1$ is temporally unstable in Fiji. Therefore, it may be said that she supports the Reserve Bank of Fiji's targeting of the rate of interest as a conduct of the monetary policy. However, her results are refuted by Rao and Singh (2005a). Rao and Singh have applied alternative time series approaches of General to Specific (GETS) and JML with annual data for Fiji from 1971-2002. They found that demand for MI in Fiji is stable and well determined. Their JML long run income 
elasticity is not significantly different from unity as their Wald test on the null of unit income elasticity was not rejected at the $5 \%$ level. At the mean interest rate of $6.97 \%$, the implied longrun interest rate elasticity of -0.26 is also plausible. Both the methods (GETS and JML) gave similar cointegrating coefficients[2].

In a more recent study, Rao and Kumar (2007) used the Gregory and Hansen procedure to test the stability of the demand for M1 in Fiji for the period 1970-2002. Their findings assert that a stable demand for $M 1$ persists in Fiji even in presence of structural breaks in the model. Jayaraman and Ward (2003) estimated demand for broad money (M2) for Samoa using quarterly data from 1987(Q1)-2000(Q4). They obtained a stable money demand function for Samoa and claim that monetary targeting is feasible policy option for Samoa. Their income elasticity of demand for M2 is around unity. The real interest rate and real exchange rate elasticities are -0.042 and -1.306 , respectively. Its worth noting that they obtained a negative real interest rate elasticity and this has the implausible implication that demand for money should raise with expected inflation.

For PNG, Kannapiran (2001) utilized annual data from 1979-1995 and the Engle-Granger method to estimate the demand for M2 in PNG. He obtained an implausibly low income elasticity of 0.20. Kumar and Manoka (2008) used GETS and JML technique to estimate demand for $M 1$ for Tonga for the period 1978-2004. Their GETS results imply that the income elasticity is unity and the interest rate elasticity at mean rate of $5.92 \%$ is -0.12 . Both the methods gave similar cointegrating coefficients. Further, they found that the demand for $M 1$ is temporally stable in Tonga. One of the implications of their findings is that money supply is the appropriate monetary policy instrument to be used by the National Reserve Bank of Tonga.

\section{Model Specification and Data}

The conventional Keynesian demand for money equation is specified where demand for real MI is expressed as a function of real income and the nominal rate of interest. Our prior expectations are that income elasticities are close to unity in these island countries. PICs have underdeveloped financial markets where most transactions involve the use of narrow money as opposed to other forms of monetary aggregates[3]. The rate of interest which measures the opportunity cost of holding money is expected to be significant with negative sign. Our basic specification is as follows:

$\ln (M / P)_{t}=\beta_{0}+\beta_{1} \ln (Y / P)_{t}-\beta_{2} R_{t}+\varepsilon_{t}$

where $M$ is narrow money, $P$ is the GDP deflator, $Y$ is the nominal GDP measured at factor cost, $R$ is the nominal weighted average interest rate on short-term time deposits and $\varepsilon$ is an iid error term. Initially we also used real exchange rate but obtained insignificant coefficients for all our selected PICs. It is obvious that in the PICs, people hold limited foreign exchange because of under-developed financial markets. The exchange rate may have significant effects on money demand in the developed countries. The inflation rate may be a better proxy for the opportunity cost of holding money, however, in our case we found that inflation rate is stationary in levels and therefore it cannot be used in our cointegration analysis. For an excellent exposition 
on unit roots and cointegration, see Rao (2007). In all cases, we found that the nominal rate of interest rate is the optimal proxy to reflect the opportunity cost of holding money. Our sample period is from 1974 to 2004, except for Samoa where consistent data is only available from 1980-2004. We use Microfit 4.1 for all estimations. Definitions of the variables and sources of data are in the Appendix 1.

We first tested for the presence of unit root in our variables. The Augmented DickyFuller tests (ADF) are used for testing for the order of the variables. The ADF tests have been applied for both levels and their first differences with an intercept and trend. The time trend is included because it is significant in the levels and first differences of the variables. The computed test statistics for the levels and first differences of the variables are given in Table 1 below. The null hypothesis of unit root cannot be rejected at the $5 \%$ level for the level variables ie. $\ln (M / P), \ln (Y / P)$ and $R$. Alternatively, the null that their first differences have unit roots is clearly rejected. There is no point in applying more sophisticated unit root tests because, compared to the ADF test, alternative unit root tests like the generalized least squares ADF test, Phillips Perron test and the Elliott, Rothenburg and Stock test have more power against the unit root null.

Table-1: ADF Unit Root Tests

\begin{tabular}{|l|l|l|l|l|l|l|l|}
\hline & Lags & $\ln (M / P)_{t}$ & $\Delta \ln (M / P)_{t}$ & $\ln (Y / P)_{t}$ & $\Delta \ln (Y / P)_{t}$ & $R_{t}$ & $\Delta R_{t}$ \\
\hline FJ & {$[1,1,2,1,2,0]$} & 1.778 & 6.407 & 2.563 & 3.618 & 1.467 & 7.945 \\
\hline VNT & {$[1,1,0,0,1,2]$,} & 1.519 & 7.976 & 2.239 & 6.075 & 0.360 & 4.313 \\
\hline SAM & {$[1,0,1,0,1,0]$} & 1.403 & 5.228 & 1.503 & 3.324 & 1.222 & 4.098 \\
\hline SOL & {$[1,2,0,0,1,0]$} & 0.790 & 5.792 & 0.346 & 8.914 & 0.293 & 3.711 \\
\hline PNG & {$[0,2,1,0,1,3]$} & 2.370 & 5.869 & 2.573 & 3.964 & 2.746 & 3.638 \\
\hline
\end{tabular}

Notes: 1 . The respective $1 \%$ and $5 \%$ critical values for ADF test are 3.685 and 2.970 .

2. Lag lengths are for the respective variables selected with AIC and SBC criteria. For example $[0,1]$ indicates that lag 0 and 1 are significant in 1 st and 2 nd columns, respectively.

3. The sample periods are: Fiji(1974-2004), Vanuatu(1974-2004), Samoa (1980-2004), Solomon(1974-2004) and PNG (1974-2004).

\section{Empirical Results}

Since our ADF test showed that the level variables contain unit roots, we shall use two alternative time series methods viz., GETS and JML, to estimate the demand for M1. First, using the GETS approach we estimated the demand for real $M 1$ with a lag length of 4 periods. These were later reduced to manageable parsimonious versions as reported in Table-2. For Fiji, the dummy variable (DUM) captures the effects of the two political instabilities of 1987 and 2000. It has a positive coefficient because the coup is likely to increase holdings of precautionary balances. For Vanuatu, the DUM represents the financial sector reforms which has positive effect as better and efficient financial systems allow improved availability of credit. Similar dummy variables were tried for other countries but they were insignificant at conventional levels. The growth in expected inflation $\left(\Delta^{2} \ln P\right)$ seems to have temporally affected the demand for $M 1$ in the PICs. 
Table-2. GETS Estimates

\begin{tabular}{|c|c|c|c|c|c|}
\hline & FJ(1) & $\mathbf{V N}(1)$ & SAM(1) & SL(1) & PNG(1) \\
\hline Intercept & $\begin{array}{l}1.123 \\
(2.23)^{*}\end{array}$ & $\begin{array}{l}0.487 \\
(7.89) *\end{array}$ & $\begin{array}{l}1.373 \\
(4.48)\end{array}$ & $\begin{array}{l}1.975 \\
(8.39)^{*}\end{array}$ & $\begin{array}{l}3.310 \\
(4.24)^{*}\end{array}$ \\
\hline Trend & $\begin{array}{l}0.478 \\
(2.21)^{*}\end{array}$ & & $\begin{array}{l}-0.034 \\
(3.83)^{*}\end{array}$ & $\begin{array}{l}0.027 \\
(8.32)^{*}\end{array}$ & $\begin{array}{l}0.047 \\
(2.14)^{*}\end{array}$ \\
\hline$\lambda$ & $\begin{array}{l}-0.512 \\
(4.78)^{*}\end{array}$ & $\begin{array}{l}-1.298 \\
(5.83)^{*}\end{array}$ & $\begin{array}{l}-0.350 \\
(3.37)^{*}\end{array}$ & $\begin{array}{l}-0.376 \\
(4.57)^{*}\end{array}$ & $\begin{array}{l}-0.378 \\
(4.30)^{*}\end{array}$ \\
\hline $\ln (Y / P)_{t-1}$ & $\begin{array}{l}1.034 \\
(5.87)^{*}\end{array}$ & $\begin{array}{l}0.957 \\
(2.94)^{*}\end{array}$ & $\begin{array}{l}1.049 \\
(2.87)^{*}\end{array}$ & $\begin{array}{l}0.983 \\
(4.89)^{*}\end{array}$ & $\begin{array}{l}1.403 \\
(3.06)^{*}\end{array}$ \\
\hline$R_{t-1}$ & $\begin{array}{l}-0.013 \\
(3.83)^{*}\end{array}$ & $\begin{array}{l}-0.099 \\
(2.55)^{*}\end{array}$ & $\begin{array}{l}-0.088 \\
(2.26)^{*}\end{array}$ & $\begin{array}{l}-0.017 \\
(3.25)^{*}\end{array}$ & $\begin{array}{l}-0.078 \\
(3.38)^{*}\end{array}$ \\
\hline$\Delta \ln (M / P)_{t-1}$ & & $\begin{array}{l}1.640 \\
(7.79)^{*}\end{array}$ & $\begin{array}{l}1.299 \\
(2.64)^{*}\end{array}$ & & \\
\hline$\Delta \ln (Y / P)_{t-1}$ & $\begin{array}{l}2.730 \\
(2.45)^{*}\end{array}$ & & & $\begin{array}{l}0.262 \\
(2.86)^{*}\end{array}$ & $\begin{array}{l}1.278 \\
(2.82)^{*}\end{array}$ \\
\hline$\Delta \ln (Y / P)_{t-2}$ & & $\begin{array}{l}2.834 \\
(3.39)^{*}\end{array}$ & & $\begin{array}{l}0.017 \\
(3.60)^{*}\end{array}$ & \\
\hline$\Delta \ln (Y / P)_{t-3}$ & $\begin{array}{l}0.557 \\
(2.76)^{*}\end{array}$ & & $\begin{array}{l}0.017 \\
(3.43)^{*}\end{array}$ & & $\begin{array}{l}2.389 \\
(3.38)^{*}\end{array}$ \\
\hline$\Delta R_{t-2}$ & & $\begin{array}{l}-0.273 \\
(2.36)^{*}\end{array}$ & $\begin{array}{l}-0.378 \\
(7.38)^{*}\end{array}$ & $\begin{array}{l}-1.280 \\
(3.12)^{*}\end{array}$ & $\begin{array}{l}-0.430 \\
(3.15)^{*}\end{array}$ \\
\hline$\Delta^{2} \ln P_{t-2}$ & $\begin{array}{l}-1.832 \\
(3.27)^{*}\end{array}$ & $\begin{array}{l}-0.384 \\
(2.48)^{*}\end{array}$ & $\begin{array}{l}-0.023 \\
(4.13)^{*}\end{array}$ & $\begin{array}{l}-0.754 \\
(4.20)^{*}\end{array}$ & $\begin{array}{l}-0.363 \\
(2.37)^{*}\end{array}$ \\
\hline$D U M$ & $\begin{array}{l}0.257 \\
(2.34)^{*}\end{array}$ & & $\begin{array}{l}0.378 \\
(2.38)^{*}\end{array}$ & & \\
\hline Adjusted $\mathrm{R}^{2}$ & 0.712 & 0.738 & 0.738 & 0.698 & 0.683 \\
\hline SEE & 0.032 & 0.089 & 0.055 & 0.087 & 0.044 \\
\hline $\mathrm{X}_{\mathrm{sc1}}^{2}$ & $(0.78)$ & $(0.23)$ & $(0.31)$ & $(0.78)$ & $(0.22)$ \\
\hline $\mathrm{X}_{\mathrm{ff}}^{2}$ & $(0.37)$ & $(0.11)$ & $(0.38)$ & $(0.30)$ & $(0.37)$ \\
\hline$X_{n}^{2}$ & $(0.23)$ & $(0.89)$ & $(0.20)$ & $(0.41)$ & $(0.83)$ \\
\hline$X_{\text {hs }}^{2}$ & $(0.91)$ & $(0.42)$ & $(0.49)$ & $(0.32)$ & $(0.53)$ \\
\hline
\end{tabular}

Absolute $t$ - ratios are below the coefficients in parentheses and for diagnostic tests $\mathrm{p}$-values are given.

$*$ indicates significance at $5 \%$ level. $\lambda$ is the speed of adjustment. The estimated parsimonious equations for Fiji, Vanuatu, Samoa, Solomons and PNG are FJ(1), VN(1), SAM(1), SL(1) and PNG(1), respectively. $D U M$ for Fiji is constructed as 1 in 1987 and 2000 and zero in other periods. DUM for Vanuatu is constructed as 1 from 1980-1990 and zero in other periods.

In Table-2, the two crucial implied long run elasticities for income and the rate of interest are significant with correct signs and expected magnitudes for all the PICs. The implied income elasticity is around unity for all, except for PNG. The implied income elasticity for PNG is slightly high at around 1.4. Perhaps this is due to high levels of corruption, warfare payments and political instability causing an increase in precautionary balances and inefficiency in the financial sector. At the respective sample means, the implied long run interest rate elasticities are -0.21 for Fiji, -0.31 for Vanuatu, -0.22 for Samoa, -0.18 for Solomons and -0.36 for PNG.

The $X^{2}$ summary statistics indicate that there is no serial correlation, functional form misspecification, non-normality and heteroscedasticity in the residuals. All the equations in Table 2 are tested for temporal stability. Neither the cumulative recursive sum of recursive residuals (CUSUM) nor the cumulative sum of squares of recursive residuals (CUSUMSQ) tests 
showed any instability (The GETS based CUSUM and CUSUMSQ test results are not reported to conserve space, but are available from the authors upon request).

Since the level variables contain unit root and their first differences are stationary, we proceed with estimating money demand for PICs with the JML approach. The optimum lag lengths of the vector auto-regressions (VARs) were tested with a $4^{\text {th }}$ order model, except for Samoa where $3^{\text {rd }}$ order was tested due to a shorter sample size. We included a constant and a trend term for all the countries. For Fiji and Vanuatu the respective dummy variables used in GETS were also incorporated. The Akaike Information Criteria (AIC) and Schwartz Bayesian Criteria (SBC) criteria were used to select the lag lengths of the VARs. In all cases, the AIC and SBC indicated lag lengths of 1 or 2 periods, except for the Solomons where $4^{\text {th }}$ order VAR was optimal. Both the Trace and Eigenvalues rejected no cointegration at $95 \%$ but did not reject the null of one long run relationship[4]. The implied cointegrating vectors (CVs) for each countries normalized on $\ln (M / P)_{t}$ are given in Table 3 below.

Table-3 JML: Implied long run Elasticities

\begin{tabular}{|l|l|l|l|l|l|}
\hline & Fiji & Vanuatu & Samoa & Solomons & PNG \\
\hline $\ln (Y / P)_{t}$ & 1.044 & 0.988 & 1.043 & 1.049 & 1.399 \\
\hline$R_{t}$ & -0.023 & -0.013 & -0.112 & -0.052 & -0.087 \\
\hline
\end{tabular}

The estimated income elasticities for all countries, except for PNG, are close to unity. For PNG, it is slightly higher at around 1.4. The implied interest rate elasticities are also significant and plausible. These are consistent with our GETS estimates given in Table 2. However, as is required, we subjected the CVs in Table 3 for identification and endogeinity tests. We found that the dis-equilibrium in the respective money markets do not significantly contribute to the explanation of $\ln (Y / P)_{t}$ and $R_{t}$ in all cases. Therefore, we can treat $\ln (Y / P)_{t}$ and $R_{t}$ as being weakly exogenous variables in all the money demand equations[5]. Adopting the lag search procedure used in the GETS equations in the second stage, we arrived at the following parsimonious JML equations reported in Table 4.

The diagnostic test results of all equations in Table 4 are reasonable. The coefficients of the lagged error terms $\left(E C M_{t-1}\right)$ have correct signs and are significant at the conventional levels. This implies the presence of negative feedback mechanisms for all the dynamic equations. All equations have reasonable standard errors (SEE). The dummy variable $(D U M)$ that represents political instability and financial reforms in Fiji and Vanuatu, respectively, are significant at 5\% level. The growth in expected inflation seems to have significant temporary effects on all money demand equations. Each of the equations in Table 4 were tested for temporal stability and neither the CUSUM nor CUSUM SQUARES test showed any instability. The stability test results (CUSUM SQUARES only) are reported in Appendix 2.

Following Poole (1970), a stable demand for money function is a necessary condition for central banks to use the money supply as an instrument of monetary policy. In the context of the PICs, stable demand for money functions imply that the financial sector reforms and liberalization policies (implemented during 1980s) is yet to have any significant effects on money demand. Singh and Kumar (2009), Kumar and Manoka (2008) and Rao and Singh (2005a) argued that 
there are limited non-bank financial institutions, lack of diversification in the financial system and low capital mobility in the PICs. Hence the unit income elasticities of money demand signifies the existence of underdeveloped financial markets in these countries.

Table-4: JML Estimates

\begin{tabular}{|c|c|c|c|c|c|}
\hline & FJ(2) & $\mathrm{VN}(2)$ & SAM(2) & SL(2) & PNG(2) \\
\hline Intercept & $\begin{array}{l}2.389 \\
(4.48) *\end{array}$ & $\begin{array}{l}0.378 \\
(1.77) * *\end{array}$ & $\begin{array}{l}0.984 \\
(4.35)^{*}\end{array}$ & $\begin{array}{l}6.270 \\
(10.27)^{*}\end{array}$ & $\begin{array}{l}3.289 \\
(2.99)^{*}\end{array}$ \\
\hline$E C M_{t-1}$ & $\begin{array}{l}-0.265 \\
(7.37)^{*}\end{array}$ & $\begin{array}{l}-0.378 \\
(4.34)^{*}\end{array}$ & $\begin{array}{l}-0.839 \\
(3.77)^{*}\end{array}$ & $\begin{array}{l}-0.272 \\
(4.27)^{*}\end{array}$ & $\begin{array}{l}-0.992 \\
(3.78)^{*}\end{array}$ \\
\hline$\Delta \ln (M / P)_{t-1}$ & & $\begin{array}{l}-2.367 \\
(1.85) * *\end{array}$ & & $\begin{array}{l}3.289 \\
(2.88)^{*}\end{array}$ & \\
\hline$\Delta \ln (M / P)_{t-2}$ & $\begin{array}{l}9.389 \\
(2.48)^{*}\end{array}$ & & $\begin{array}{l}2.388 \\
(3.37)^{*}\end{array}$ & & $\begin{array}{l}3.278 \\
(2.38)^{*}\end{array}$ \\
\hline$\Delta \ln (M / P)_{t-3}$ & $\begin{array}{l}0.278 \\
(8.37)^{*}\end{array}$ & & & $\begin{array}{l}1.289 \\
(2.98)^{*}\end{array}$ & $\begin{array}{l}1.920 \\
(4.26)^{*}\end{array}$ \\
\hline$\Delta \ln (Y / P)_{t-1}$ & & $\begin{array}{l}1.278 \\
(4.46)^{*}\end{array}$ & $\begin{array}{l}1.289 \\
(3.37)^{*}\end{array}$ & & \\
\hline$\Delta \ln (Y / P)_{t-2}$ & $\begin{array}{l}1.278 \\
(2.11)^{*}\end{array}$ & & & & \\
\hline$\Delta R_{t-1}$ & & & $\begin{array}{l}-0.168 \\
(2.36)^{*}\end{array}$ & $\begin{array}{l}-0.326 \\
(5.58)^{*}\end{array}$ & $\begin{array}{l}-0.367 \\
(1.85)^{* *}\end{array}$ \\
\hline$\Delta R_{t-2}$ & & $\begin{array}{l}-0.273 \\
(2.36)^{*}\end{array}$ & $\begin{array}{l}-0.267 \\
(1.69)^{* *}\end{array}$ & & \\
\hline$\Delta^{2} \ln P_{t-1}$ & & $\begin{array}{l}-0.236 \\
(5.57)^{*}\end{array}$ & & & \\
\hline$\Delta^{2} \ln P_{t-2}$ & $\begin{array}{l}-0.278 \\
(6.54)^{*}\end{array}$ & & $\begin{array}{l}-3.478 \\
(3.26)^{*}\end{array}$ & $\begin{array}{l}-0.538 \\
(4.48)^{*}\end{array}$ & $\begin{array}{l}-1.670 \\
(2.37)^{*}\end{array}$ \\
\hline$D U M$ & $\begin{array}{l}0.337 \\
(2.98)^{*}\end{array}$ & & $\begin{array}{l}0.283 \\
(4.25)^{*}\end{array}$ & & \\
\hline Adjusted $\mathrm{R}^{2}$ & 0.883 & 0.784 & 0.623 & 0.713 & 0.663 \\
\hline SEE & 0.021 & 0.067 & 0.089 & 0.055 & 0.052 \\
\hline $\mathrm{X}_{\mathrm{sc} 1}^{2}$ & $(0.72)$ & $(0.11)$ & $(0.27)$ & $(0.27)$ & $(0.88)$ \\
\hline $\mathrm{X}_{\mathrm{ff}}^{2}$ & $(0.12)$ & $(0.38)$ & $(0.90)$ & $(0.93)$ & $(0.18)$ \\
\hline$X_{n}^{2}$ & $(0.83)$ & $(0.88)$ & $(0.23)$ & $(0.73)$ & $(0.28)$ \\
\hline $\mathrm{X}_{\mathrm{hs}}^{2}$ & $(0.74)$ & $(0.56)$ & $(0.64)$ & $(0.19)$ & $(0.38)$ \\
\hline
\end{tabular}

Absolute $t$-ratios are below the coefficients in parentheses and for diagnostic tests p-values are given.

$*$ and $* *$ indicates significance at 5\% and $10 \%$ levels, respectively. The estimated parsimonious equations for Fiji, Vanuatu, Samoa, Solomons and PNG are FJ(2), VN(2), SAM(2), SL(2) and PNG(2), respectively.

\section{Conclusions}

In this paper, we have briefly surveyed previous works on the demand for money in the Pacific Island Countries (PICs). It may be argued that the studies prior to Rao and Singh (2005a) that is Katafono (2001), Kannapiran (2001) and Jayaraman and Ward (2003) have limitations in their specification and therefore their long run income and rate of interest elasticities are either overestimated or under-estimated. This paper makes contribution to the literature by estimating the money demand functions using the newest time series techniques for a group of PICs over the period 1974-2004. Specifically, we have applied alternative time series methods of the General 
to Specific (GETS) and the Johansen Maximum Likelihood (JML) to estimate demand for M1 for the PICs viz, Fiji, Vanuatu, Samoa, Solomon and PNG. Both the methods gave similar and consistent cointegrating coefficients although their dynamic adjustments are somewhat different. Our results imply that income elasticities are around unity for all the selected PICs, except for the PNG where it is around 1.4. The interest rate elasticities are negative and slightly vary from country to country.

Many developing countries have started targeting the rate of interest without significant evidence that their money demand functions have become unstable. For instance, Fiji has changed its monetary policy target from money supply to bank rate in 1997. Similar approach is also being taken by other PICs such as Samoa, Vanuatu, Solomons and PNG. Our results imply that the demand for MI in the PICs are temporally stable and therefore, money supply is the appropriate monetary policy instrument for these central banks. However, if the monetary authorities follow the developed and advanced countries and target the rate of interest, according to Poole (1970), that would cause more instability in the income levels.

\section{Notes}

1. Except for Samoa, where data is from 1980-2004.

2. Later Rao and Singh (2005b) have used Hendry and Krolzig's PcGets software and arrived at the same conclusion about the income and interest rate elasticities of money demand for Fiji. Similar conclusions have also been made by Singh and Kumar (2009) in the context of the money demand in 15 developing countries.

3. In developed countries, income elasticities are expected to be much lower than unity due to better financial systems with e-commerce and internet banking services which lowers the cost of transactions and reduces the use of liquid assets such as M1. For an empirical survey of income elasticities for developed and developing countries, see Sriram (1999).

4. The individual country specific details of Trace and Eigenvalues are not reported to conserve space. However these can be requested from the authors.

5. The procedure for indentification and endogeinity tests are well explained in Rao (2006). These results are not reported to conserve space. It can obtained from authors upon request. For more details on alternative time series techniques, see Bahmani-Oskooee and Rehman (2005), Rao and Kumar (2008) and Kumar (2007, 2008 \& 2009). 


\section{Appendix 1}

$P=$ GDP deflator (1995=100). Data are derived from International Financial Statistics (IFS2005).

$Y=$ Nominal GDP at factor cost for Fiji, but it is at market prices for the other PICs. Data are from (IFS-2005) and ADB database(2005).

$R=$ The average of 1-3 years savings deposit rate for Fiji. For the others, it is the average shortterm deposit rates (3-9 months). Data obtained from (IFS-2005) and ADB database (2005).

$M 1=$ Currency in circulation and demand deposit. Data obtained from (IFS-2005) and ADB database (2005).

$D U M=$ Dummy variable. $D U M$ for Fiji is constructed as 1 in 1987 and 2000 and zero in other periods. DUM for Vanuatu is constructed as 1 from 1980-1990 and zero in other periods.

Notes:

1. All variables, except the rate of interest, are deflated with the GDP deflator and converted to natural logs. 


\section{Appendix 2}

\section{Figure 1: Plot of CUSUMSQ Tests for Fiji (JML)}

Plot of Cumulative Sum of Squares of Recursive Residuals

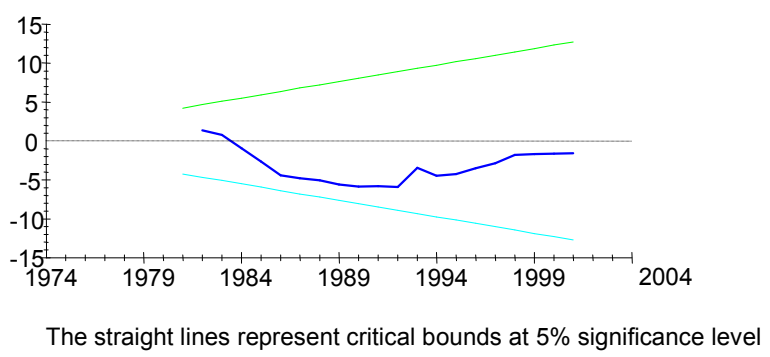

Figure 2: Plot of CUSUMSQ Tests for Vanuatu (JML)

Plot of Cumulative Sum of Squares of Recursive Residuals

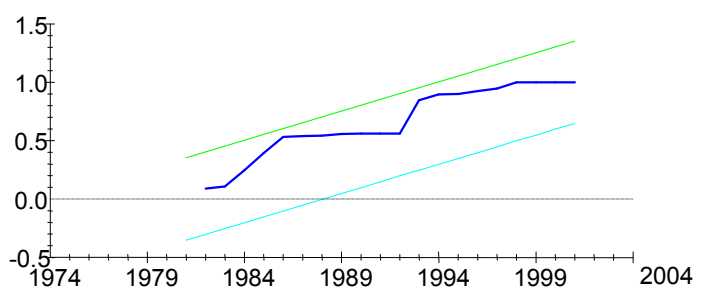

The straight lines represent critical bounds at $5 \%$ significance level 
Figure 3: Plot of CUSUMSQ Tests for Solomons (JML)

Plot of Cumulative Sum of Squares of Recursive Residuals

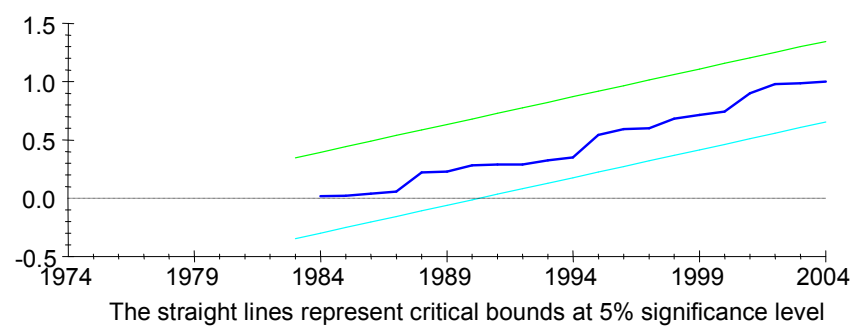

Figure 4: Plot of CUSUMSQ Tests for PNG (JML)

Plot of Cumulative Sum of Squares of Recursive Residuals

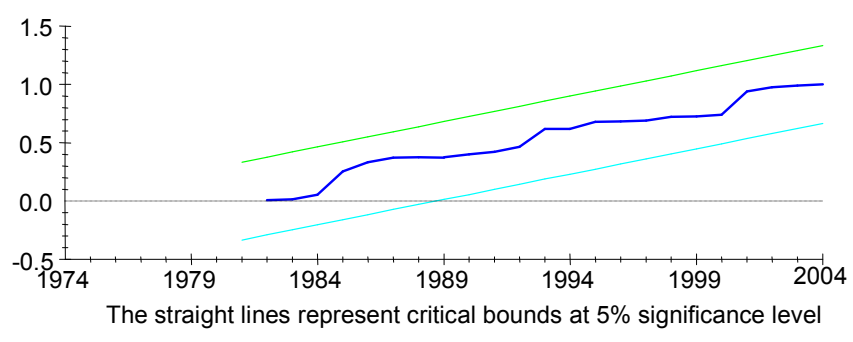


Figure 5: Plot of CUSUMSQ Tests for Samoa (JML)

Plot of Cumulative Sum of Squares of Recursive Residuals

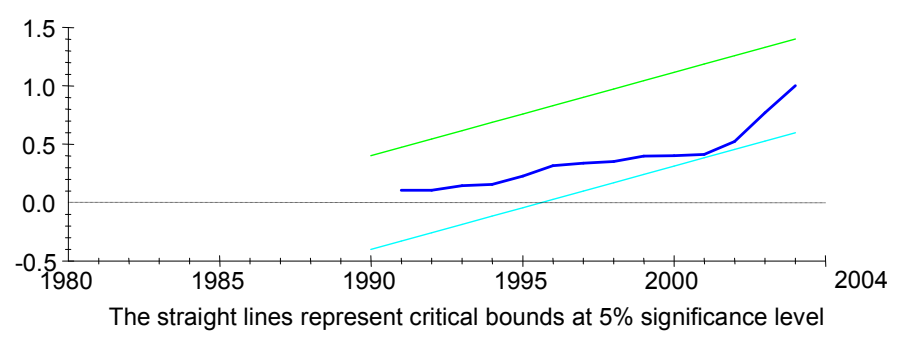




\section{References}

Bahmani-Oskooee, M. and Rehman, H. (2005) "Stability of the Money Demand Function in Asian Developing Countries," Applied Economics, Vol. 37, pp. 773-792.

International Financial Statistics, December, 2003. IMF CD-ROM (Washington DC: International Monetary Fund).

Jayaraman, T.K. and Ward, B.D. (2003) "Impact of Financial Sector Reforms and Stability of Money Demand Functions in Samoa," in Jayaraman, T.K., Issues in Monetary Economics of the South Pacific Island Countries, Suva: The University of the South Pacific.

Kannapiran, C. (2001) "Stability of Money Demand and Monetary Policy in Papua New Guinea: An Error Correction Model Analysis," International Economic Journal, Vol.15, pp. 7384.

Katafono, R. (2001)“Demand for Money in Fiji,” Staff Working paper (03/2001). Suva: The Reserve Bank of Fiji.

Kumar, S. (2009) "A Re-examination of Private Consumption in Fiji," Pacific Economic Bulletin, Vol. 24, pp.70-81.

(2008) "Income and Price Elasticities of Exports in Philippines," The ICFAI Journal of Applied Economics, Vol. VII, pp.40-46.

(2007) "The Stability of Demand for Money in Bangladesh: Time Series Methods," The ICFAI Journal of Monetary Economics, Vol. V, pp. 27-35.

Kumar, S. and Manoka, B. (2008) "Testing the Stability of Demand for Money in Tonga," The Empirical Economics Letters, Vol.7, pp.835-843.

Pesaran, M. and Pesaran, B. (1997) Working with Microfit 4.0. Oxford: Oxford University Press.

Poole, W. (1970) "The Optimal Choice of Monetary Policy Instruments in a Simple Macro model," Quarterly Journal of Economics, Vol.7, pp.192-216.

Rao, B.B. (2007) "Cointegration for the Applied Economist," 2nd Edition, Hampshire: Macmillan Publishers Limited.

(2006) "Estimating Short and Long run Relationships: A Guide to Applied Economists," forthcoming in Applied Economics.

Rao, B.B and Kumar, S. (2009) "A Panel Data Approach to the Demand for Money and the Effects of Financial Reforms in the Asian Countries," forthcoming in the Economic Modelling. 
(2008) "Cointegration, Structural Breaks and the Demand for Money in Bangladesh,” Applied Economics, Vol. 24, pp. 1-20.

(2007) "Structural Breaks, Demand for Money and Monetary Policy in Fiji,” Pacific Economic Bulletin, Vol.22, pp.54-62.

Rao, B. and Singh, R. (2005a) "Cointegration and Error Correction Approach to the Demand for Money in Fiji," Pacific Economic Bulletin, Vol.2, pp.72-86.

Letters, forthcoming.

Singh, R. and Kumar, S. (2009) "Application of the Alternative Techniques to Estimate Demand for Money in Developing Countries," forthcoming in the Journal of Developing Areas.

Sriram, S. S., (1999) "Survey of Literature on Demand for Money: The Cointegration and Demand for Money in PICs Theoretical and Empirical Work with Special Reference to Error-Correction Models," IMF Working Paper 7WP/99/64 (Washington DC: International Monetary Fund).

The Asian Development Bank, (2005) "Economic and Financial Update - 2005," Key Indicators of Developing Asia and Pacific Countries. Manilla: The Asian Development Bank.

\section{Corresponding Author and Acknowledgements}

The corresponding author is Saten Kumar, School of Business Economics, Faculty of Business and Law, AUT University, Auckland, New Zealand. Email: kumar_saten@yahoo.com

We would like to thank Professor Bill. B. Rao for useful comments on an earlier version of this paper. 